\title{
Learning the natural law as maturation in wisdom
}

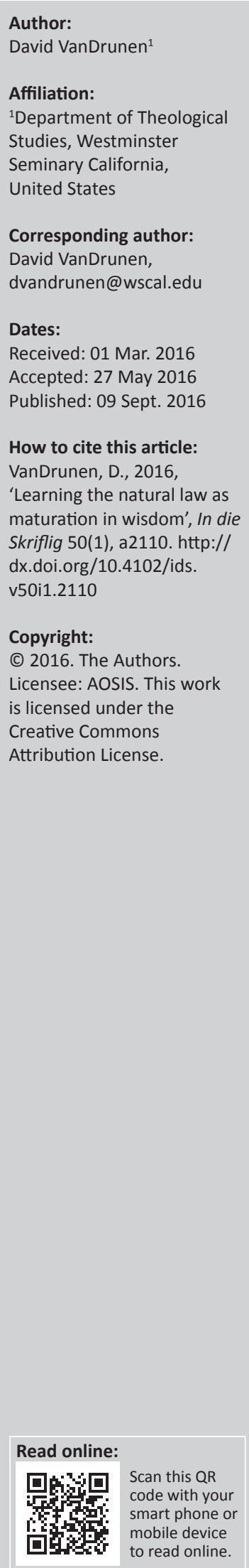

Despite the technical character of natural law scholarship, most people who live in accord with the natural law do not do so because they have been persuaded by technical argumentation. How do people truly come to know the natural law? Learning the natural law is essentially the same process as maturing in wisdom. Building upon theological conceptions of natural law and wisdom, this article concludes that wisdom is the suitable power by which people apprehend subjectively what the natural law prescribes objectively. Thus the way in which we grow in wisdom - through a communal process of receiving instruction and observing and reflecting upon life experience - is also the primary way in which people come to know and practice the natural law. This conclusion suggests a revised perspective on how natural lawyers pursue their work as they seek to address the moral fragmentation of our day.

Many discussions of natural law transpire at a sophisticated level of rational argumentation. Some of them contend for controversial moral positions, directed against those who reject the natural law or at least what the natural law allegedly teaches (e.g. Girgis, Anderson \& George 2012). At other times proponents of natural law polemise against each other, defending one version of natural law theory over against alternatives. Recent debates about the 'new natural law theory' and the relationship of practical and speculative reason provide a good example of the latter (e.g. George 1999; Grisez, Boyle \& Finnis 1987; Hittinger 1987; Jensen 2015).

Such discussions have their value. It is important for natural lawyers to continue developing rational arguments on important moral controversies and engaging in internal discussion about natural law's relation to practical and speculative reason. The character of these discussions, however, risks obscuring a matter of considerable importance. Few if any people come to understand and practice the natural law because a technical rational argument has persuaded them. Most people who understand and practice the natural law are not intellectuals at all, but ordinary people who live well in their homes, neighbourhoods, and workplaces. They may not even be able to identify the term natural law, but they honour its moral substance and follow its direction, without the benefit of any sophisticated rational argument. Natural lawyers themselves attain philosophical or theological sophistication only after long years of study, and thus only after absorbing and embracing particular moral perspectives that inevitably shape the way they construct and evaluate moral arguments.

This reality should encourage natural lawyers to inquire carefully into how people truly come to know the law of nature. In this article I explore the relationship of understanding the natural law to maturation in wisdom. Growing in wisdom, I argue, is the same process as learning to know and practice the natural law. The ordinary people who live well in their homes, neighbourhoods, and workplaces may not be philosophically sophisticated, but they are wise. Thus, if we wish to know how people truly come to know the law of nature, we need to identify how people gain wisdom.

The broader natural law tradition has recognised the kinship between wisdom and natural law. Thomas Aquinas' (1948) conception of natural law depends upon wisdom. ${ }^{1}$ More recently the theme emerges here and there among writers representing a range of perspective and interest (Deane-Drummond 2007; International Theological Commission 2014:31-34; Parsons 1999; VanDrunen 2014:367-414). Building upon some of this work, I attempt to explain and defend my thesis that equates learning the natural law with maturation in wisdom, albeit with some qualification.

I firstly explain what I understand by the idea of natural law, drawing especially on notions of the image of God and the biblical covenants. Then I argue that wisdom consists in knowing and

1.Thomas Aquinas (1948:I-il Q. 93 A. 1) asserts that the type of Divine Wisdom ... bears the character of law. Accordingly the eternal law is nothing else than the type of Divine Wisdom, as directing all actions and movement'. Since Thomas defines the eternal law elsewhere as the 'Divine Reason' governing the world (1948:I-II Q. 91 A.1), he thinks of eternal law as God's government of the world through both his wisdom and his reason. Hence the natural law, the rational creatures' participation in the eternal law (1948:I-II Q. 91 A.2), must be understood as a participation in God's wisdom (compare 1948:I-II Q. 94 A.2). 
practicing the natural law. This argument implies that if we wish to know how people come to learn the natural law we need to know how people come to grow in wisdom. In the final section I reflect on how this growth in wisdom takes place, according to the book of Proverbs in particular, and what the implications are for natural law theory. When people are not immersed in the ways of wisdom, I conclude, they will have great difficulty appreciating the force of good natural law arguments.

This study considers natural law from a theological perspective, and specifically a reformed Christian perspective. Its argument is not overly parochial, however, it builds upon the Scriptures, in conversation with the broader western moral tradition (including Roman Catholic, Jewish, and ancient Greek sources) and with contemporary psychology, philosophy of science, and complexity theory.

\section{The natural law as royal commission}

My argument about natural law and wisdom obviously depends upon a certain conception of natural law. In this section I set forth a necessarily brief account grounded in Christian theology, especially pertaining to doctrines of the image of God, the divine covenants, and common grace, with particular focus on the early chapters of Genesis. While I acknowledge that natural law is accessible to all people through their ordinary human faculties, Christian Scripture and theology teach conceptions of creation, providence, and anthropology that provide a framework for those wishing to reflect upon the natural law in ways consistent with their Christian faith. This section explores part of that framework as a prelude to the consideration of natural law and wisdom that follows. The basic claim is this: natural law is not a collection of rules but a moral order that directs the human race to fulfill a commission that is inherent to those who bear the image of God.

Since natural law refers to a law known by nature, and thus to a law that is in accord with human nature as it exists within a broader natural order, the doctrine of creation is crucial to any theological study of this topic. In Genesis 1 creation climaxes with the formation of human beings in God's image:

Then God said, 'Let us make man in our image, after our likeness. And let them have dominion over the fish of the sea and over the birds of the heavens and over the livestock and over all the earth and over every creeping thing that creeps on the earth'. (Gn 1:26) ${ }^{2}$

The grammar and context of this statement suggest that the commission to exercise dominion is essential and not incidental to creation in God's image. God made human beings in his image in order that they might rule the broader created order under God's ultimate authority (Joüon 1991:381). As God exercised sovereign rule by ordering the world, he commissioned those who bear his likeness to exercise a delegated rule by governing it. According to much of the Christian tradition the image of God consists in certain

2.Scripture translations are taken from The Holy Bible, English Standard Version (2001). ontological attributes or capabilities such as reason, freedom, and moral responsibility. Genesis 1:26 surely presupposes such things, but it presents the image as an active rather than a static concept. To bear God's image is to have a royal commission. Prominent early reformed theologians such as Wolfgang Musculus (cf. Thompson 2012:47) and Herman Witsius (1990:57), as well as the Westminster Shorter and Larger Catechisms (Answers 10 and 17, respectively), recognised dominion as an aspect of image-bearing, and several contemporary reformed theologians have defended and developed this idea (Horton 2005:96-112; Kline 1980:1334; VanDrunen 2014:46-50). Many recent Old Testament exegetical studies have also embraced versions of this view (e.g. Bird 1981:138; Clines 1998:490-92; Middleton 2005:5354; Miller 2011:70-71). This view has striking implications for the fundamental equality and dignity of all human beings: since all people bear the image of God, God calls all people not just privileged people who have political power - to share in the royal rule of this world.

The notion of human dominion has raised suspicion that Judeo-Christian ideas are the root cause of contemporary environmental crises. But using Genesis 1:26, 28 to justify ecological degradation is an abuse of the text. Although the Hebrew words translated 'have dominion' and 'subdue' can indicate harsh use of power, they do not necessarily mean this (Garr 2003:171; VanDrunen 2014:47-48). In the context of Genesis 1, the text presents God's creative dominion as one of benevolence and generosity. By ordaining that human dominion should be like God's Genesis 1 also implies that human dominion must be benevolent and generous, promoting not only humanity's good but also the good of the world it rules (VanDrunen 2014:58-61, 66-67). God delegates rightful authority but not tyrannical power.

Genesis 1 provides a framework for constructing a natural law theory consistent with Christian conviction. God has made human beings in his image, and this image defines theologically what human nature is (at least in part). To be human is to receive a moral vocation, a royal commission. ${ }^{3}$ Thus the royal commission is the original natural law (VanDrunen 2014:86-94). Genesis 1:26, 28 of course reveal the royal commission as a matter of special revelation. Yet God did not deliver this special revelation as a piece of arbitrary positive law. The royal commission was a moral calling that followed inherently from the kind of creature God made humans to be. ${ }^{4}$ To have a divine-image-bearing nature

3.The claims of Herbert A. Simon, a leading scholar of complexity theory, suggest indirect support for this conclusion. Simon argues that people are relatively simple, and the complexity of their behaviour stems from their search for good designs within the complex environments in which they live; cf. Simon 1996:51-84). If this is correct we can only understand human nature and human behaviour in the context of humanity's ongoing quest to understand the world around them and to forge technological advance, crucial aspects which I am calling the royal commission. If we do not pursue the commission, we would not be the kind of creatures we are.

4.Everywhere that humanity expresses its curiosity and itch for exploration confirms that the royal commission follows inherently from our nature. The string theorist that the royal commission follows inherently from our nature. The string theorist Brian Gr 2015): We are a species of expl math. What aets us fired up are unexplored lands - sometimes literally, as when we send something to the outer solar system, and sometimes abstractly, when we explore the new lands of quantum mechanics, relativity and string theory. ... When the mind soars, it goes far. (p. 3) 
entailed the vocation to be fruitful, multiply, fill, subdue, and rule. The royal commission was natural law because to pursue this vocation was to live in accord with human nature as created by God.

Furthermore, if the royal commission was the original natural law then the original natural law was teleological in character. It directed humanity toward fulfilment of interrelated goals (cf. Simon 1996:81). This also means that the original natural law cannot be reduced to a set of rules. Whatever rules this natural law implied must be seen in connection with its teleological goals and interpreted in their light. ${ }^{5}$

In the preceding paragraph I referred to the 'original' natural law, anticipating another crucial Christian doctrine addressed early in Genesis, the fall into sin. The doctrine of the fall creates a potential problem for a Christian account of natural law. If the world is no longer in a state of integrity, but lies under a divine curse that infects both human nature and the broader natural order (Gn 3:14-19; 6:5; 8:21), it is unclear whether and to what extent conclusions about natural law drawn from Genesis 1 still hold. The covenant with Noah (Gn 8:21-9:17) provides an answer: the conclusions drawn from Genesis 1 generally hold true, but require modification. Human beings, despite the fall, continue to bear God's image (Gn 9:6) and thus to have a natural moral calling in this world (Gn 9:1-7). This calling resembles the original royal commission in many respects, especially by reordaining human beings to be fruitful and multiply and fill the earth (Gn 9:1, 7). It also implies that human beings are to exercise dominion under God's authority, although it presents this dominion more modestly than Genesis 1 does, speaking not of subduing the world but of eating animals humanely ( $\mathrm{Gn}$ 9:3-4) and enforcing justice against the violent (Gn 9:6). The fact that human beings are now intrinsically sinful (Gn 6:5; $8: 21$ ) and unable to complete the original vocation to subdue the world, likely explains these differences between Genesis 9 and Genesis 1. But the account of the Noahic covenant justifies referring to the natural law, even after the fall, as a teleological royal commission that obligates human beings by nature as image-bearers of God (VanDrunen 2014:123-128; cf. also Burnside 2011:79; International Theological Commission 2014:40; Novak 2000:84-85; 2005:30-64). The Noahic covenant indicates that this natural law remains a potent reality in God's providential government of the world but also that sinful humanity is only partially able to obey it.

What more can be said about the moral content of the natural law? How exactly are human beings to pursue their natural law commission to fill the earth and exercise some measure of just rule within it? To begin answering these questions I observe that the royal commission is an exceedingly complex vocation. It is tempting for contemporary readers to think of filling the earth as rather elementary, but in fact the global

\footnotetext{
5.This original natural law also appears to be eschatological as well as teleological in character, although I cannot develop this point here. The natural-law royal commission called the human race to attain not only goals internal to the origina created order but also everlasting fellowship with God in a new creation. This ide has ancient roots, across various Christian traditions (e.g. Augustine 1950:12.21; John of Damascus 1958:II.11; Thomas Aquinas 1948:1-II Q. 3 A. 8: I-II Q. 109 A. 5; and Witsius 1990:50-161)
}

expansion of humanity has been a feat of amazing proportions. Filling the earth has taken much more than just a lot of sexual intercourse. It required the development of innumerable technological advances, alongside the establishment of myriad social structures to enable, support, and to protect these advances (cf. Simon 1996:154-155). With respect to technology, the worldwide expansion of humanity has required the development and continual improvement of agriculture and the practice of medicine, which in turn has required the development of a host of practical skills and of intellectual disciplines such as mathematics, engineering, and the natural sciences. With respect to social structures, the expansion of humanity has called for the establishment of families on a small-scale level but also legal, political, and economic institutions on a larger level and these latter institutions require increasing complexity as populations grow. What the human race has already accomplished in advancing the royal commission is astounding.

These observations suggest that the development of technology and the establishment of social structures, alongside the many skills and disciplines that accompany them, are essential components of what the natural law, as royal commission, requires of the human race.

This conclusion reveals problems, or at least insufficiencies, in natural law scholarship. Natural lawyers often seek to construct rational arguments that identify a set of moral precepts, which they present as the moral substance of the natural law. ${ }^{6}$ Undoubtedly (at least some of) the moral precepts they identify have something to do with the natural law; it seems perfectly accurate to say that 'do not murder', 'do not commit adultery', and 'do not steal', for example, are natural moral obligations. But equating natural law with a set of moral precepts is insufficient, for one thing because these precepts are predominantly negative in character. Negative precepts provide necessary constraints on human behavior that deflects people from the teleological goal of the royal commission, but they provide little positive direction toward achieving the goal.

Another problem runs deeper. The familiar natural law precepts, whether negative or positive, are of limited use apart from a concrete social context in which to interpret and implement them. To take the three relatively non-controversial precepts mentioned above: one cannot know how to avoid theft without economic structures that determine how property is owned and transferred, one cannot engage in a chaste sexual union apart from familial structures that specify marriage relationships, and one cannot even protect human life properly without a legal order that distinguishes guilt from innocence and hence regulates the boundaries of just coercion (cf. Fuller 1969:205-206). These are well-known challenges to natural law theory. Even to the degree that

6.Although the International Theological Commission (2014) has concerns similar to mine, expressed by rejecting the idea of natural law as a rigid moral code, which it associates especially with 'the matural law' (p. 48), it definition of naturallaw speaks of 'expressing these [fundamental] orientations [o moral action] in a normative fashion in the form of precepts or commandments' ( $p$ 30). Even so some commentators worry that the Commission is not clear enough about the importance of precepts (e.g. Hittinger 2014:117-119). 
natural lawyers can persuasively identify universally obligatory precepts through rational argumentation, these precepts tend to suffer from under-specification (see Porter 2005 ; 2009).

I return to my previous claim: the development and refinement of technology and social structures, with the various skills and disciplines they require, are essential aspects of what the natural law as royal commission demands of the human race. Taking the moral exhortations of the Noahic covenant as a basic summary of the royal commission in our fallen world, I elaborate this claim as follows: the natural law royal commission calls human beings to establish families that support the work of producing, raising, and training children (Gn 9:1,7), to develop corporate institutions that support the work of technological innovation and economic growth (Gn 9:3-4), and to develop legal and political institutions that maintain justice in society (Gn 9:56). One might object that speaking of natural law in this way also suffers from under-specification. In a sense this is true. I do not claim that natural law provides an exact blueprint for how many such institutions there ought to be and what their responsibilities and authority structures ought to be, let alone for how they should interrelate in the complexities of social life. Natural law points in the direction of what must be done, without specifying exactly how. Yet natural law still regulates these efforts. Many possible institutions must be judged contrary to the natural law royal commission because they hinder the tasks of childrearing, technological development, economic growth, and enforcement of justice. The realities of human nature and of the broader natural order provide constant constraints upon human action. Particular practices will prove themselves over time to be more or less effective in promoting the goals of the royal commission.

At the heart of these reflections is the idea that fulfilment of the natural law royal commission entails a long process of experimentation, construction, and refinement, and thus nobody could possibly have figured out by abstract rational contemplation all that needed to happen in order to make significant strides toward the commission's goals. What the human race has achieved thus far is inseparable from the vast array of familial, corporate, legal, and political institutions that interrelate through a complex network of laws and customs, all of which could never have been rationally designed by any person or group of persons, and cannot be thoroughly comprehended even once they exist (see Barnett 2014:29-132; Hayek 1973).

The discussion thus far suggests a definition for natural law, namely natural law is the royal commission to which God calls the human race as image-bearers, directing them to be fruitful, multiply, fill the earth, and exercise a benevolent rule in the world through the development of families and of corporate and legal institutions that promote childrearing, technological advance, economic growth, and justice. An extended set of moral rules cannot be the heart of natural law, because rules have limited concrete meaning apart from the development of institutions and the practices by which they operate and interrelate. Given this social context, however, moral rules do play an important and even necessary role by providing instruction and boundaries for living within the increasingly complex societies that pursuit of the royal commission inevitably produces. Therefore the natural law, thus understood, is at heart a moral order rather than a set of rules, although rules provide summaries of its substance and compass points for its successful navigation. ${ }^{7}$

\section{Wisdom as perception of the natural law}

This section begins to consider explicitly the chief concern of this article, namely the relationship of natural law and wisdom. I argue that if natural law is what I have just claimed it is, wisdom is perception of the natural law. To put it another way: as taught in the Christian Scriptures (and echoed to some degree in other traditions), wisdom is the ability to understand and practice the natural law as it directs us toward fulfilment of the royal commission. I use Proverbs as the principle source for describing what wisdom is.

I begin with a clarification and a qualification. Firstly to clarify: while I interpret wisdom as a thoroughly moral reality, I believe it encompasses the development of knowledge and use of skills that are not moral, strictly speaking. For example wise farmers farm with excellence and deserve praise for it. In performing this work they fulfil a moral vocation, but this vocation entails not-strictly-moral knowledge of soil conditions and weather patterns and notstrictly-moral skills of planting, fertilising, watering, and harvesting. Thus part of their moral vocation is to pursue such not-strictly-moral knowledge and skills.

Secondly to qualify: the kind of wisdom considered here is attainable, at least in part, through experience of and reflection upon the natural order of this world. To use traditional reformed theological categories, this wisdom is rooted in natural revelation, although special revelation (especially Proverbs) also discusses and promotes it. ${ }^{8}$ But special revelation also speaks of a wisdom known only through Christ crucified, and is not accessible through the natural order (cf. 1 Cor 1:18-3:23; Col 2:2-3). Perhaps the former is best termed a 'proximate' wisdom and the latter an 'ultimate' wisdom. The latter transcends without cancelling

\footnotetext{
7.1 suggest another way to consider this: If one insists that the essence of the natural law is a set of moral precepts, then the concept of application becomes crucial, since no set of precepts could possibly cover all possible circumstances. Precept must always be applied. But what keeps the application of precepts from becoming arbitrary? What normatively guides the process of application? It is difficult to see how application can be anything other than arbitrary unless one makes application in the context of a moral order underlying the precepts, which in turn suggests that the moral order is actually more fundamental than the precepts, even in this precept-application approach.

8.In reformed theology, natural revelation refers to God's revelation in the natural order while special revelation refers to God's revelation through Christ, the prophets, and Scripture (cf. Bavinck 2003:301-385). Proverbs is one place where Scripture says much about this wisdom acquired, in part, from natural revelation. Scripture says much about this wisdom acquired, in part, from natural revelation. For example by incorporating material from Gentile sources, Proverbs recognises the presence of a genuine wisdom outside the bounds of Israel ( $\operatorname{Pr} 22: 17-24: 22$ $30: 1-9 ; 31: 1-9)$. Elsewhere the Old Testament acknowledges the wisdom of Gentiles: 1 Kings 4:30; Job 1:3; Jeremiah 49:7; Ezekiel 14:14, 20; 28:3; and Obadiah 8 (cf. also VanDrunen 2014:393-398). Proverbs of course is addressed specifically to Old Testament Israel, and interpretation of this book needs to be attentive to both the universal and the particular aspects of its teaching.
} 
out the former. ${ }^{9}$ How Christ is the highest expression of divine wisdom is an important topic in its own right, but it is not my interest here.

To address the main concern of this section: In Proverbs as well as in popular parlance, wisdom is a moral and intellectual power (or virtue) by which people understand which courses of conduct are good and bad and are able to put this knowledge into skillful practice. In order to unpack this idea further and to demonstrate wisdom's relation to natural law, it is helpful to consider at first a couple of things that wisdom is not.

Firstly, wisdom does not consist in the memorisation of moral rules. Even the ordinary observer knows the difference between a wise person and someone who can recite a list of commandments. Proverbs points in the same direction. Much of Proverbs proceeds by way of short sayings. These sayings are not rules but observations about life and counsel for conduct, the accuracy of which holds true generally, but not always universally. Many observations about how life works prove to be inaccurate in particular circumstances. For example the proverb that states 'train up a child in the way he should go; even when he is old he will not depart from it' (Pr 22:6) accurately observes the way things generally operate but obviously not the way matters always turn out. Likewise, sometimes individual proverbs give mutually contradictory counsel. For example Proverbs 26:4 advises, 'answer not a fool according to his folly', while the following verse (26:5) advises, 'answer a fool according to his folly'. Since only one of these options can be followed in each relevant situation, neither one is a rule, strictly speaking (cf. Murphy 2002:10-11).

Secondly, wisdom also does consist in the application of rules to particular circumstances. Proverbs challenges a conventional opinion, namely that the key role of wisdom is to fill gaps that moral rules do not clearly cover..$^{10}$ In contrast to this idea Proverbs teaches that observing basic and obvious moral rules is itself a manifestation of wisdom. For example the extended prologue of Proverbs (1-9) repeatedly emphasises the folly of adultery (Pr 5:1-23; 6:20-35; 7:4-27). Wisdom keeps a young man 'from the forbidden woman, from the adulteress with her smooth words' (7:5). 'Do not commit adultery' is a straightforward precept included in most short lists of essential moral rules, and yet the prologue of Proverbs asserts that observing this precept exemplifies wisdom. Here wisdom does not apply a clear rule to a borderline case but grasps the gravity of an unambiguous act of adultery and understands how to avoid it. Wisdom does involve discerning what to do in difficult cases not covered by a standard set of rules but Proverbs indicates that this is not wisdom's essence.

A better way to understand wisdom is as a perception or sense of how the world works and thus of what sort of conduct is

9.International Theological Commission (2014:41) reflects on the Old Testament wisdom literature in several ways similar to my understanding of 'proximate' wisdom Its treatment of matters pertaining to Christology, soteriology, and the wisdom. Its treatment of matters pertaining to Christology, soteriology, and the era debates, with my understanding of 'ultimate' wisdom (VanDrunen 2014:84-90) era debates, with my understanding of 'ultimate' wisdom
Similar differences appear in Cloutier (2014:218-220).

10.International Theological Commission (2014:60) does not put it this way, but in my judgement it is too ready to associate the need for wisdom with making 'concrete applications' of the natural law. likely to be effective or destructive in particular circumstances. ${ }^{11}$ It grasps what behaviour is fitting in a concrete time and place in the light of its effects upon the actor and those surrounding her (cf. Crenshaw 1998:11). Hence Proverbs proceeds not by presenting lists of clear rules or showing how to apply clear rules to borderline moral problems, but by helping readers recognise recurring patterns, patterns of how certain kinds of character traits produce certain kinds of behaviour and of how certain kinds of behaviour reap certain kinds of fruit. $^{12}$ Proverbs multiples analogies revealing the true character of certain types of people and certain types of conduct, by likening them to various phenomena in the wide world around. It instills a way of seeing the world and a connoisseur's taste for apt speech and behaviour (cf. Fox 2000:32-33; Weeks 1994:74-75; Whybray 1994:32-33). ${ }^{13}$

Perhaps implied in the preceding, but worth stating clearly, is that Proverbs also presents wisdom as the skillful action that puts this perception into practice. In the Old Testament the Hebrew word for wisdom describes not moral philosophers but God, craftsmen, and kings, all of whom display wisdom in action (cf. Heaton 1974:18-19). 'By wisdom' God 'founded the earth' and 'established the heavens' (Pr 3:19); elsewhere the Old Testament uses the same verbs to describe human construction of cities, houses, and temples (e.g. 1 Kings 6:37; 1 Chronicles 17:24; Ezra 3:12; Isaiah 14:32; cf. Van Leeuwen 1997:53-54). Throughout Proverbs the wise person is industrious and the fool lazy (e.g. 10:5; 12:11, 24; 18:9; 19:24; $21: 25 ; 26: 13-16)$. As God brought order out of chaos in creating the world (8:27-29), so wise farmers clear weedy fields to produce a crop, wise parents discipline unruly children to keep them on the straight path, and wise rulers bring justice to troubled societies (e.g. 27:23-27; 22:6; 20:8; cf. also Dell 2006:142; Fox 2000:279-280, 355-356).

More than just an intellectual knowledge, therefore wisdom also consists in skills that enable people to accomplish difficult but rewarding tasks. Perhaps Michael Polanyi's (1962) concept of 'personal knowledge' gets at something of what Proverbs communicates. Polanyi argues that maxims, or rules of art, govern certain activities and guide those who undertake them. But these maxims can never possibly substitute for skills. Polanyi (1962:29-30) suggests that there are true maxims of golf and poetry, which give insight into these activities, but 'these maxims would instantly condemn themselves to absurdity if they tried to replace the golfer's skill or the poet's art'. Elsewhere he (Polanyi 1962) notes:

the 'well-known fact that the aim of a skillful performance is achieved by the observance of a set of rules which are not known as such to the person following them'. (p. 49; italics - MP)

11.Aristotle's notion (2011:Vi) of phronesis, or practical wisdom, points in the same direction. More recently, psychologist Elkhonon Goldberg (2005:79) refers to wisdom as 'a deep insight into the nature of things, but also ... a keen understanding of what action needs to be taken to change them'

12. Similarly Goldberg (2005:85) discusses how the human brain grows in abilities of 'pattern recognition', 'the organism's ability to recognize a new object or a new problem as a member of an already familiar class of objects or problems'. In their study of casuistry Albert R. Jonsen and Stephen Toulmin $(1998: 40,44,252)$ argue for the importance of pattern recognition, analogical reasoning, and the like for ethics.

13. Another way to put it is that wisdom resides in certain sorts of people - people of virtuous character (cf. Brown 1996). 
This is clearly true. The real master of golf is not the television commentator, but the exquisite player, whether or not she can describe exactly what makes her game effective. The true master of poetry is not the literature professor who analyses beautiful poems, but the one who writes them, whether or not he can explain the delightfulness of his verse. The accomplished golfer and poet have 'personal knowledge' of their arts. The same dynamic seems to be at work in Proverbs. The wise person is not so much the soil scientist as the farmer who gathers a bountiful crop, not so much the political theorist as the king who does justice, not so much the parenting guru as a mother or father who raises children well. This is not to deny that the competent soil scientist, political theorist, and parenting guru possess a genuine wisdom as well - as Simon (1996:93) puts it, 'the boundary between knowledge and skill is subtle' - but Proverbs emphasises the wisdom of practical skill more than that of intellectual analysis.

While hardly a comprehensive account, the preceding discussion provides a sketch of wisdom: not in essence a knowledge of rules or of how to apply such rules, but a perception of how the world works and what sort of conduct is therefore effective and fitting, a perception that resides not only in the intellect but also in practical skills that enable execution of difficult but profitable activities. And to return to the main claim of this section: wisdom is the ability to understand and practice the natural law that directs us toward fulfilment of the royal commission. Several points of correspondence between my discussions of natural law and wisdom support this conclusion.

Firstly and most fundamentally, natural law understood as a moral order rather than a series of rules, corresponds perfectly to wisdom, understood not as a knowledge of rules or how to apply rules but as a perception of how the world works and what sort of conduct is fitting within it. Wisdom is the appropriate subjective faculty for apprehending the objective norm of natural law. Different objects of knowledge call for different abilities in the knower. Knowing the capitols of European nations requires powers of memorisation; knowing arithmetic requires powers of computation. Knowing the natural law, a moral order advancing the royal commission, requires powers of perception. Another way to put it is that engaging the natural law is more an art than an exact science. While people can write helpful books about diagnosing illnesses or navigating ships - or playing golf or writing poetry - expert physicians, captains, golfers, and poets possess a never-fully-describable skill, with a perception of or taste for what makes for excellence in their particular fields. Likewise, while people can write helpful books describing the natural law as royal commission, true knowledge of something so complex demands the perception of a craftsman and the taste of a connoisseur. And such perception and taste are precisely what constitute wisdom.

Secondly, wisdom and natural law correspond not only because of how wisdom knows but also because of what wisdom seems particularly concerned to know. I argued above that the natural law as royal commission requires technological advance and economic growth. Proverbs was composed long before development of the modern market economy that has done so much in many respects to facilitate advance of the royal commission, yet Proverbs exudes a spirit of enterprise. Industriousness is one of the most prised features of wisdom, while Proverbs ridicules the lazy man as the paragon of folly (e.g. Pr 10:5; 12:11, 24; 18:9; 19:24; 21:25; 26:13-16). The industry of the wise is not mere busyness, however, but is effective for turning little into much and scarcity into profit. Good people save up wealth little by little and make it grow (13:11), leaving an inheritance for their children's children (13:22). They work their land and have bread (12:11), bringing an abundant harvest out of fallow ground (13:23). The profitable industry of the wise woman at the end of Proverbs leaves readers out of breath. She not only cares for regular domestic chores such as preparing food and making clothes (Pr 31:15, 19-22, 27) but also plays the entrepreneur. She does research, purchases a field, and plants a vineyard (31:16). She buys raw materials from afar, turns them into valuable goods, and sells them to merchants (31:1314, 18-19,24). Thus the natural law's demand for technological advance and economic growth corresponds to the spirit of enterprise and entrepreneurial skill that wisdom instills.

In the previous section I argued that the Noahic covenant presents the natural law royal commission not only in terms of technological advance and economic growth but also in terms of being fruitful, multiplying, filling the earth, and administering justice (Gn 9:1, 5-7). Proverbs has a great deal to say about these as well. Wisdom resides in finding a good spouse (18:22), training children (22:6), and maintaining domestic joy (15:17). From the outset Proverbs presents education in wisdom through the guise of a father instructing his son $(\operatorname{Pr} 1: 8 ; 2: 1 ; 3: 1 ; 4: 1 ; 5: 1 ; 6: 1 ; 7: 1)$. Justice is also a pervasive theme in Proverbs. God is just (24:12) and an inscrutable justice seems to permeate the order of things, such that good tends to come to those who act well and destruction to those who do evil (e.g. Pr 11:25; 21:5; 26:27). Wisdom guides the government of rulers (8:15-16), condemns bribery (17:23), supports the cause of the needy (31:9), and renders right judgement (17:15). Thus wisdom again corresponds to natural law. The matters that constitute the core of the natural law are precisely those to which wisdom especially attends.

A third and final point of correspondence is worth noting. As argued above nobody could have constructed from scratch the details of what the natural law royal commission prescribes. To attain what the human race has already accomplished toward this end has required the development of complex networks of laws and institutions through an extended historical process. Accordingly, wise people do not gain their perception and skill as blank slates operating in a vacuum. They gain them in ways that depend upon the achievements of those who have gone before them. In youth the wise learn from their parents and throughout life they seek counsel from others, accept correction, and honor the elderly. They gather knowledge through experience and evaluate new situations by comparison to old ones. As explored further below, the wise thoroughly depend upon 
the accumulation of insight that one generation passes down to the next and that inheres in the fabric of the social order. Both wisdom and knowledge of the natural law depend upon the long flow of history.

Thus wisdom and natural law correspond: wisdom is the suitable way for human beings to apprehend subjectively what the natural law prescribes objectively. Wisdom is the ability to understand and practice the natural law that directs us toward fulfilment of the royal commission.

\section{Learning the natural law as maturation in wisdom}

This article began by asking how people come to know and practice the natural law. Few if any people do so through persuasion by sophisticated rational argumentation - the common mode of natural law scholarship - and thus something else must explain how morally upright people have actually gained their knowledge of it. If what I have argued thus far is true, and wisdom is indeed a perception of the natural law, then the following must also be true: maturing in wisdom is essentially the same thing as coming to know and practice the natural law. Thus I propose an answer to the original question: people come to know and practice the natural law by becoming wise. In this final section I therefore investigate how people mature in wisdom.

The end of the previous section pointed toward an answer by portraying growth in wisdom as a communal process (cf. also Hittinger 2014:118; Polanyi 1962:203, 249, 266; Porter 2009:91). Both the adjective and noun are important. Growth in wisdom is communal both in the sense that wisdom resides in communities and in the sense that individuals gain wisdom through participation in communities. And growth in wisdom is a process in that there are no short cuts to attaining wisdom, which is dearly acquired. On the individual level wisdom is the achievement of a lifetime and on the communal level the achievement of successive generations.

Proverbs makes clear that learning wisdom on an individual level is designed to begin from youth (cf. Aristotle 2011:II.1). It counsells parents to train their children with prospects for success if pursued well (e.g. Pr 22:6), and exhorts children to heed their parents' instruction (e.g. 1:8-9). In adulthood people should both receive and solicit instruction from a widening circle of teachers. The wise give heed when others correct or instruct them (e.g. 10:8; 12:15; 19:20). They do not merely wait for the outspoken neighbour to offer serendipitous advice, but also actively seek the counsel of others as they contemplate their course of life (e.g. 15:20; 13:20). Thus learning wisdom is a communal process first of all because it entails the continual absorption and implementation of instruction from others. ${ }^{14}$

14.Polanyi $(1962: 53-54,62-63,207)$ notes that this transmission of wisdom canno merely be by 'prescription' but also, and perhaps especially, 'by example from master to apprentice'.
This process is not limited to learning what others are able to pass down. Proverbs also describes the wise as gaining insights through a kind of self-education. This is perhaps most evident in how Proverbs guides readers through the experience of observation, reflection, and moral conclusion (cf. Clements 1992:21; Perdue 1994:109-110; compare Aristotle 2011:VI.8). A passerby notices the dilapidated state of the sluggard's property (Pr 24:30-31), thinks about it (24:32), and concludes: 'a little sleep, a little slumber, a little folding of the hands to rest, and poverty will come upon you like a robber, and want like an armed man' (24:33-34). A wise person attentive to ants goes through a similar process and draws an identical conclusion (6:6-10). Someone else observes a young man seduced by a married woman, sees how it ruins his life, and recognises the folly of adultery (7:6-23). These people had probably been taught by others to shun laziness and adultery, but there was something powerful about seeing things for themselves. The process of observation, reflection, and conclusion brings insight into the true character of foolish behaviour that mere warnings from others may not. Wise people therefore are constantly alert to the world around them and eager to gain new insight to incorporate into the beneficial knowledge they have learned by instruction - and to filter out foolish instruction they have also absorbed. But this new insight is dependent upon knowledge already learned. This is particularly evident in the importance of analogical reasoning (cf. Clements 1992:45-46; Crenshaw 1998:55; Perdue 2008:11). Proverbs constantly compares certain kinds of people and certain kinds of behaviour to a variety of well-known phenomena in the wider world (e.g. 25:11-14, 18-20, 25-26, 28). Through processes of patternrecognition the wise person learns about new things by comparing them to the old (cf. Goldberg 2005:20-21, 55, 76, 85, 149; Polanyi 1962:103; Simon 1996:88-89).

The wise person participates in an ongoing, intergenerational process of gaining insight about the world and effective conduct within it. By receiving and soliciting instruction the wise tap into a store of social capital they could never have created on their own, and by personal observation and reflection they not only refine their own understanding but may also be able to add some small contribution to the store that they transmit to the next generation. ${ }^{15}$ As wise people before them from time immemorial have received instruction, improved upon it, and passed it along, so the wise today pursue the same end. ${ }^{16}$ This individual experience is intertwined with communal experience. Societies large and small, political and otherwise, exercise wisdom when they nurture the gains of the past alongside attempts to gain 15.Along analogous lines, International Theological Commission (2014:33) states that the world's wisdom traditions 'constitute a type of "cultural capital" available in the search for a common wisdom necessary for responding to contemporary challenges'. Language itself is part of this social capital (cf. Goldberg 2005:89-94; Polanyi 1962:112; Simon 1996:45).

16.These considerations support the notion common to many traditions that wisdom belongs to the aged. Proverbs associates wisdom with gray hair and often accords elo pecial honour to the elderly (e.g. Pr 16.31, 20.29). Modern psychological research has suggested that the brain in middle age and beyond, although past its peak in erms of memorising and powers associated with wisdom, thanks to its store of experience and web of wellfiled and interconnected long-term memories (Goldberg 2005; Strauch 2010; cf. also Hartshorne \& Germine 2015). 
insight in the present. The ethical method of casuistry and the Anglo-American judicial method of common law seem to provide formal procedures for resolving moral problems and legal disputes in ways that reflect this perspective, insofar as they seek insight from past precedent, analogise to new situations, and forge resolutions that will serve in turn as precedent for the future (Jonsen \& Toulmin 1988; Kronman 1993:11-162; Polanyi 1962:53-54; Stoner 2003:11$12,23,153)$.

Thus people come to know and understand the natural law in the same way they mature in wisdom, namely through a social process. This process begins in youth and continues throughout life. They receive and solicit instruction and combine the knowledge thus acquired with enriched and refined insights gained through their own observations, reflections, and conclusions, all of which instill a perception of how the world works and therefore what sort of conduct is fitting within it in order to promote the royal commission.

What I have argued may seem somewhat idealised: the description of a process that sounds nice in theory but is unlikely to transpire so smoothly in reality. But in fact I do not claim that this process runs smoothly in real life. I claim that this is the path to gaining wisdom - that is, to learning the natural law - but folly continually interrupts and diverts human beings individually and socially from steady travel upon it. On the one hand, the tragedy of human folly may blind us to just how much the human race has accomplished toward the ends of the royal commission. The growth of the human population and its diffusion throughout much of the globe, enabled by the development of languages, laws, and institutions, which in turn have enabled profound technological and economic advance, indicate that we have accumulated over time a treasury of wisdom and understanding of the natural law. Contemporary individuals who participate in the achievements of this project partake of this treasury in smaller or larger ways. Even the mildly competent person has amazing abilities to cope with the challenges of life. On the other hand, the wisest societies and individuals exhibit shocking displays of folly. The seemingly most civilised communities have perpetrated barbaric atrocities; highly accomplished people destroy their families and careers through sophomoric scandals. The human race pursues a bizarre course of knowing the natural law and simultaneously suppressing it - a suppression Paul describes as people turning into 'fools' (Rm 1:18-22, 32; 2:14-15).

In certain respects my proposal may seem far too pessimistic and gloomy, rather than optimistically idealised. If my argument is accurate, then being born to foolish parents or into a corrupt broader society severely impairs people's prospects for attaining wisdom and thus for learning the natural law, due to factors entirely out of their control. Some people obviously overcome these hurdles in part, just as some people born into relatively wise cultural contexts squander their advantages, but our lifelong dependence upon the wisdom already attained in our social contexts is a sobering fact that can hardly be overestimated. Maturation in wisdom is inescapably a communal process, and thus our ability to learn the natural law is enabled and constrained in profound ways by the social structures in which we participate (cf. Polanyi 1962:216-222).

\section{Conclusion}

In this article I have argued that natural law and wisdom correspond. Wisdom is the appropriate subjective ability necessary to apprehend the objective standard of natural law, understood as a moral order directing the human race toward fulfilment of its royal commission as image-bearers of God. This means that learning the natural law is essentially the same thing as maturing in wisdom. It also explains why those who live in relative accord with the natural law do not do so because someone has persuaded them through a sophisticated rational argument. They do so because they have become immersed in the path of wisdom, in most cases already from youth although some overcome deficient upbringings through good instruction and diligent observation and reflection later in life (perhaps aided by a religious conversion).

The argument of this article also contributes to explaining why natural lawyers' sophisticated rational arguments seem so seldom to persuade those committed to contrary views. To be sound and solid natural law arguments must tap into the store of wisdom without which the natural law is incomprehensible. However, that store of wisdom is attractive only to those who have been acculturated in its ways and have gained the perception and insight it provides for understanding the world and how to live effectively within it. Those not duly acculturated, who lack this perception and insight, lack the wherewithal to appreciate the persuasiveness of such arguments. This has little to do with powers of memory or computation. It simply means that people who set themselves up against the genuine norms of the natural law are not able to see the world in ways that make sense of these arguments. ${ }^{17}$ They are foolish. Proverbs emphasises that it is very difficult to make headway arguing with foolish people (Pr 15:12; 21:24; 23:9). To be effective natural lawyers need to be just as attentive to promoting maturation in wisdom as they are to the rigor of their technical argumentation.

\section{Acknowledgements Competing interests}

The author declares that he has no financial or personal relationships which may have inappropriately influenced him in writing this article.

17.This conclusion suggests sympathy with the following statement by Alasdair $\mathrm{C}$ Maclntyre (although I refrain from further comment on his larger project to which Macintyre (although I refrain from further comment on his larger project to which this statement is related). Maclntyre (2009) claims: 'The outcome of my arguments is notably at odds with what some Thomistic writers have claimed and many other have presupposed, namely that Thomists have resources that should enable them to refute their opponents in ways that are or should be compelling to any rationa individual, whatever her or his standpoint. This I am committed to denying'. (p. 51 cf. also Hittinger 2014:122; Polanyi 1962:151) 


\section{References}

Aquinas, T., 1948, Summa theologiae, transl. Fathers of the English Dominican Province, Benziger Brothers, New York.

Aristotle, 2011, Nicomachean ethics, transl. R.C. Bartlett \& S.D. Collins, University of Chicago Press, Chicago, IL.

Augustine, 1950, The city of God, transl. M. Dodd, The Modern Library, New York.

Barnett, R.E., 2014, The structure of liberty: Justice and the rule of law, 2nd edn., Oxford University Press, New York.

Bavinck, H., 2003, Reformed dogmatics, vol. 1: Prolegomena, J. Bolt (ed.), transl. J. Vriend, Baker Academic, Grand Rapids, MI.

Bible, 2001, The Holy Bible, English standard version, Good News Publishers, Wheaton, IL.

Bird, P.A., 1981, "Male and female He created them": Gen 1:27b in the context of the priestly account of creation', Harvard Theological Review 74(2), 129-159. http:// dx.doi.org/10.1017/S0017816000030558

Brown, W.P., 1996, Character in crisis: A fresh approach to the wisdom literature of the Old Testament, Eerdmans, Grand Rapids, MI.

Burnside, J.P., 2011, God, justice, and society: Aspects of law and legality in the Bible Oxford University Press, Oxford.

Clements, R.E., 1992, Wisdom in theology, Eerdmans, Grand Rapids, MI.

Clines, D.J.A., 1998, On the way to the Postmodern: Old Testament essays, 1967-1998, vol. 2, Sheffield Academic Press, Sheffield, pp. 447-497.

Cloutier, D., 2014, 'Seeing the whole: How protestants help us read the natural law', in J. Berkman \& W.C. Mattison III (eds.), Searching for a universal ethic: Multidisciplinary, ecumenical, and interfaith responses to the catholic natural law tradition, pp. 211-221, Eerdmans, Grand Rapids, MI.

Crenshaw, J.L., 1998, Old Testament wisdom: An introduction, Westminster John Knox, Louisville, $\mathrm{KY}$.

Deane-Drummond, C., 2007, 'Plumbing the depths: A recovery of natural law and natural wisdom in the context of debates about evolutionary purpose', Zygon 42(4), 981-998. http://dx.doi.org/10.1111/j.1467-9744.2007.00884.x

Dell, K.J., 2006, The book of Proverbs in social and theological context, Cambridge University Press, Cambridge.

Fox, M.V., 2000, Proverbs 1-9, The Anchor Bible, vol. 18a, Doubleday, New York.

Fuller, L.L., 1969, The morality of law, rev. edn., Yale University Press, New Haven, CT.

Garr, W.R., 2003, In his own image and likeness: Humanity, divinity, and monotheism, Brill, Leiden.

George, R.P., 1999, In defense of natural law, Clarendon, Oxford

Girgis, S., Anderson, R.T. \& George, R.P., 2012, What is marriage? Man and woman: A defense, Encounter, New York.

Goldberg, E., 2005, The wisdom paradox: How your mind can grow stronger as your brain grows older, Gotham, New York.

Grisez, G., Boyle, J. \& Finnis, J., 1987, 'Practical principles, moral truth, and ultimate ends', American Journal of Jurisprudence 32(1), 99-151. http://dx.doi. org/10.1093/ajj/32.1.99

Hartshorne, J.K. \& Germine, L.T., 2015, 'When does cognitive functioning peak? The asynchronous rise and fall of different cognitive abilities across the life span' Psychological Science 26, 433-443. http://dx.doi.org/10.1177/0956797614567339

Hayek, F.A., 1973, Law, legislation and liberty, vol. 1: Rules and order, University of Chicago Press, Chicago, IL.

Heaton, E.W., 1974, Solomon's new men: The emergence of ancient Israel as a national state, Pica, New York.

Hittinger, R., 1987, A critique of the new natural law theory, University of Notre Dame Press, Notre Dame, IN.

Hittinger, R., 2014, 'The situation of natural law in catholic theology', in J. Berkman \& W.C. Mattison III (eds.), Searching for a universal ethic: Multidisciplinary, ecumenical, and interfaith responses to the catholic natural law tradition, $\mathrm{pp}$ 111-122, Eerdmans, Grand Rapids, MI.

Horton, M.S., 2005, Lord and servant: A covenant Christology, Westminster John Knox, Louisville, KY.
Hotz, R.L., 2015, 'Pluto is just a baby step for humankind', Wall Street Journal 3.

International Theological Commission, 2014, 'In search of a universal ethics: A new look at the natural law', in J. Berkman \& W.C. Mattison III (eds.) Searching for a universal ethic: Multidisciplinary, ecumenical, and interfaith responses to the catholic natural law tradition, pp. 25-92, Eerdmans, Grand Rapids, MI.

Jensen, S.J., 2015, Knowing the natural law: From precepts and inclinations to deriving oughts, Catholic University of America Press, Washington, DC.

John of Damascus, 1958, 'An exact exposition of the orthodox faith', in The fathers of the church, vol. 37, transl. F.C. Chase Jr., pp. 165-406, Fathers of the Church, New York.

Jonsen, A.R. \& Toulmin, S., 1988, The abuse of casuistry: A history of moral reasoning, University of California Press, Berkeley, CA.

Joüon, P.S.J., 1991, A grammar of biblical Hebrew, vol. 2, transl. T. Muraoka, Editrice Pontificio Instituto Biblico, Rome.

Kline, M.G., 1980, Images of the spirit, Baker, Grand Rapids, MI.

Kronman, A.T., 1993, The lost lawyer: Failing ideals of the legal profession, The Belknap Press, Harvard University Press, Cambridge, MA.

MacIntyre, A.C., 2009, 'Intractable moral disagreements', in L.S. Cunningham (ed.), Intractable disputes about the natural law: Alasdair Maclntyre and critics, pp. 1-52, University of Notre Dame Press, Notre Dame, IN.

Middleton, J.R., 2005, The liberating image: The imago Dei in Genesis 1, Brazos, Grand Rapids, MI.

Miller, G.P., 2011, The ways of a king: Legal and political ideas in the Bible, Vandenhoeck \& Ruprecht, Göttingen.

Murphy, R.E., 2002, The tree of life: An exploration of biblical wisdom literature, 3rd edn., Eerdmans, Grand Rapids, MI.

Novak, D., 2000, Covenantal rights: A study in Jewish political theory, Princeton University Press, Princeton, NJ.

Novak, D., 2005, The Jewish social contract: An essay in political theology, Princeton University Press, Princeton, NJ.

Parsons, S.F., 1999, 'Wisdom and natural law: A Christian feminist enquiry', in S.C. Barton (ed.), Where shall wisdom be found? Wisdom in the Bible, the church and the contemporary world, pp. 279-293, Clark, Edinburgh.

Perdue, L.G., 1994, Wisdom \& creation: The theology of wisdom literature, Abingdon, Nashville, TN.

Perdue, L.G., 2008, The sword and the stylus: An introduction to wisdom in the age of empires, Eerdmans, Grand Rapids, MI.

Polanyi, M., 1962, Personal knowledge: Towards a post-critical philosophy, University of Chicago Press, Chicago, IL.

Porter, J., 2005, Nature as reason: A Thomistic theory of the natural law, Eerdmans, Grand Rapids, IL.

Porter, J., 2009, 'Does the natural law provide a universally valid morality?', in L.C. Cunningham (ed.), Intractable disputes about the natural law: Alasdair Maclntyre and critics, pp. 53-95, University of Notre Dame Press, Notre Dame, IN.

Simon, H.A., 1996, The sciences of the artificial, 3rd edn., MIT, Cambridge.

Stoner, J.R. Jr., 2003, Common-law liberty: Rethinking American constitutionalism, University Press of Kansas, Lawrence, KS.

Strauch, B., 2010, The secret life of the grown-up brain: The surprising talents of the middle-aged mind, Viking, New York.

Thompson, J.L. (ed.), 2012, Genesis 1-11: Reformation commentary on Scripture, Old Testament, vol. 1, InterVarsity Academic, Downers Grove, IL.

VanDrunen, D., 2014, Divine covenants and moral order: A biblical theology of natural law, Eerdmans, Grand Rapids, MI.

Van Leeuwen, R.C., 1997, Proverbs, Abingdon, Nashville, TN.

Weeks, S., 1994, Early Israelite wisdom, Oxford University Press, Oxford.

Whybray, R.N., 1994, Proverbs, Eerdmans, Grand Rapids, MI.

Witsius, H., 1990, The economy of the covenants between God and man: Comprehending a complete body of divinity, vol. 1, transl. W. Crookshank, P\&R, Phillipsburg, NJ. 